\title{
An Experimental Model on the Mechanical Properties of Reactive Powder Concrete by using Cement Replacement of Glass Powder
}

\author{
T. Raghavendra, C. Ramanjaneyulu, V. Bhuvaneswar Reddy
}

\begin{abstract}
Reactive Powder Concrete is a creating composite material that enables the solid business to advance material utilizes Generate financial advantages and building structures which are solid, strong and delicate to condition. RPC is another ultra-elite cement with extensive variety of capacities. RPC was created in the 1990s by Bouygues' research center in France. RPC speaks to another class of Portland concrete based material with compressive qualities of 120-200 MPa go. By presenting fine steel filaments. It has no coarse materials and contains little steel filaments that give extra strength. RPC incorporate Portland concrete, silica rage, fine sand, super plasticizer, water and steel strands. In this investigation, RPC by utilizing cement substitution of glass powder up to 30\%. Likewise mechanical properties, compressive strength and split tensile strength were considered.
\end{abstract}

Index Terms: Quartz powder, silica fume, steel fibers, Glass powder, compressive strength, split tensile strength.

\section{INTRODUCTION}

The development of high quality materials for enhancement of Reactive-Powder Concrete (RPC) plays a key interest in cement making system. This system focuses on half-and-half foot interaction at Sherbrooke in the place of Canada as illustrated in Fig.1, finished in the year of 1997, it was the primary structure designed by using of RPC material.

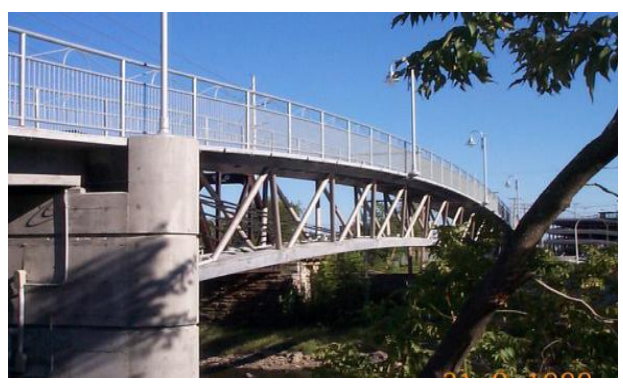

Fig.1. Sherbrook Bridge

In these years 1997 and 1998, the RPC materials are forwarded to Civaux plants and light-emissions are the major mechanical system. The primary UHPC street connects outlined and developed at Bourges' laboratory in France in 2001. Ultra elite cement is described principally with high quality $\left(>150 \mathrm{~N} / \mathrm{mm}^{2}\right)$, and when it is strengthened with steel strands, shows high pliability. Ultra high quality solid

Revised Manuscript Received on July 22, 2019

T. Raghavendra, Assistant Professor, RGM College of Engineering and Technology, Nandayal, Ananthpur, India.

C. Ramanjaneyulu, Assistant Professor, RGM College of Engineering and Technology, Nandayal, Ananthpur, India

V. Bhuvaneswar Reddy, M.Tech Student Scholar, RGM College of Engineering and Technology, Nandayal, Ananthpur, India quality can be depicted on the association of its constituent materials and calcium-silicate-hydrates (CSH). Alteration of RPC quality ought to be conceivable by including quartz powder as one of the crucial constituent fragments. At present, the RPC with quartz powder to solid extent of $30 \%$ and steam reestablishing technique in an autoclave temperature of $250^{\circ} \mathrm{C}$, can accomplish a high compressive nature of $180 \mathrm{~N} / \mathrm{mm}^{2}$ and has a truly high flexibility [1].

For the substitution of quartz powder in the RPC, the glass particles demonstrated satisfactory specific properties, for instance, compressive quality, flexural quality, and modulus of adaptability. Another good position, the glass particles has a working pozzolanic material in view of the indistinct silica as the glass-creation material. When it is mixed with calcium from portlandite $(\mathrm{Ca}(\mathrm{OH}) 2)$, will outline a second sort of $\mathrm{CSH}$, which improves the properties of concrete [2].

In this examination, the objective of exhibiting the glass powder in the RPC is to check the difference in mechanical direct of RPC, for instance, its compressive quality, flexural quality and split versatility. Likewise, concerning the usage of adjacent and reused material, glass powder from the waste glass shards material of cabin industry is used.

\section{Objectives}

So the essential goal of the present examination is encountered the generation of RPC material. In general, major issues of this investigation carried on these parameters as shown below;

- To create RPC material as high-quality compressive which is greater than $120-180 \mathrm{~N} / \mathrm{mm}^{2}$

- To lessen fine total substance along these lines, Cement is supplanted by Glass powder. Since target compressive quality is accomplished, in RPC blend.

- $\quad$ RPC blends are planned by variety in Glass powder content

\section{LITERATURE SURVEY}

The extensive research work carried by both international and national level has been done based on utilization of several additive mixtures in bond and mortars with a sharing criteria. To extract the customary bond properties based on desired fitting level to pre-requisite limitations. To grow-cost monetary forms and down-size of bonds assembled with top and square notch concrete materials. Several researchers accomplishes the observations on RPC material in past, conducts the attractive survey on definite materials. Analysts have considered on picking fixings, decision of relieving administration, molecule pressing of blend

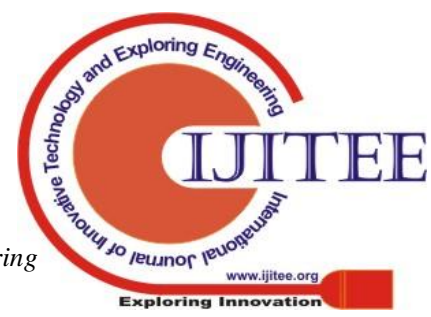


extents to evaluate the mechanical properties. A portion of the works completed are talked about beneath Richard and Cheyrezy [1995] [3] built up a ultra-high quality pliable cement composed RPC material with essential standards of improving the constituent based on wiping out of the unrefined total, upgrading the micro-structure by pre-set affability treatment, likewise, flexibility and rigidity of cement is expanded by fusing little, large ductile, straight microfibers [4]. Two kinds of cements are produced and assigned as RPC material 200 and RPC material 800. The pertained cements had uncommon properties, brought based on end of fortification, and decreasing material bringing about decrease of actual weight bringing about more-cost investment funds [5]-[9].

\section{SEVERAL MATERIAL PROPERTIES}

Cement: The Ordinary-Portland Cement (OPC) of 53-grade by Ultra-Tech affirmation to ISO:12269/1987, the specific gravity of bond is related to the value of 3.1 .

Table.1 Physical and Chemical Properties of 53 Grade OPC

\begin{tabular}{|c|c|c|}
\hline S. no & Material Properties & $\begin{array}{c}\text { Test-System } \\
\text { Results }\end{array}$ \\
\hline 1 & Usual Specific-Gravity & 3.1 \\
\hline 2 & High-Fineness Factor & $2 \%$ \\
\hline 3 & $\begin{array}{c}\text { High-Standard } \\
\text { Consistency }\end{array}$ & $32 \%$ \\
\hline 4 & Initial setting time(Min) & 90 \\
\hline 5 & Initial setting time(Min) & 230 \\
\hline
\end{tabular}

Water: Consumable water was utilized for blending. As per Bureau of Indian standard the $\mathrm{P}^{\mathrm{H}}$ value to be Maintain for curing the concrete is $6.5-8$. The obtained $\mathrm{P}^{\mathrm{H}}$ value of water which is used for curing cubes in this Research work is $\mathrm{P}^{\mathrm{H}}$ 7.23 .

Quartz Powder: The various blends of RPC material related to relieved temperature with extra silica which is important relies the $\mathrm{Cao} / \mathrm{SiO}$ mixture of folio. In this way the mixture of powder-quartz flour with an utilized mean size of 10-15 $\mu \mathrm{m}$. The powder of quartz material attained from Astra-Synthetic collections, Chennai. The specific gravity is nearly 2.6 and measured molecular range with a value of 10 to $45 \mu \mathrm{m}$.

Glass powder: Glass is essentially made out of silica. Glass powder is brought from Astra chemicals in Chennai. Glass powder measure use in $300 \mathrm{MESH}$.

Fine Aggregate: RPC is delivered utilizing produced sand having molecule measure under $2.36 \mathrm{~mm}$. The two-unique degrees are utilized, attained size in between $1.18 \mathrm{~mm}$ to $2.36 \mathrm{~mm}$, sometimes in the range of $1.18 \mathrm{~mm}$ to 600 micron in several extents.

Silica fume: A very receptive silica pozzolan is a basic part of RPC material. Silica rage is attained from Astra chemicals in Chennai. The additional properties of silica are specified in the accompanying Table.2.
Table.2 The Specific Physical-Properties of Silica-Fumes

\begin{tabular}{|l|l|}
\hline Property of Material & Result \\
\hline Size of Particle & $0.5 . \mu \mathrm{m}$ to $1 . \mu \mathrm{m}$ \\
\hline Density Value of Pack & $0.76 \mathrm{gm} / \mathrm{cc}$ \\
\hline Moisture Level & $0.058 \%$ \\
\hline Specific-Gravity level & 2.63 \\
\hline
\end{tabular}

Super plasticizer: The Ace-Glenium sky-8630 and Glenium-6100 are considered as poly-carboxylic material treated and utilized as super-plasticizer. It is attained from BASF-Polymers \& Synthetic concoctions, Pakistan (Pvt) Ltd. development synthetic substances - Karachi. Properties of super plasticizer are illustrated in Table.3.

Table.3 Properties of Super Plasticizer Material

\begin{tabular}{|c|c|}
\hline Feature & Light brown liquid \\
\hline Relative Density & $1.08+0.01$ at $25^{\circ} \mathrm{c}$ \\
\hline $\mathbf{P}^{\mathrm{H}}$ level & $\geq 6$ at $25^{0} \mathrm{c}$ \\
\hline Chloride ion content & $<0.2 \%$ \\
\hline
\end{tabular}

Steel fibers: Snare ended steel strands are utilized as view point proportion with a value of 50 with a length and diameter of $30 \mathrm{~mm}$ and $0.60 \mathrm{~mm}$. It is achieved from ASTRAA CHEMICALS CHENNAI .The physical properties related to steel strands are presented as per the following Table.4.

Table. 4 Chemical composition of steel fibers

\begin{tabular}{|c|c|}
\hline $\begin{array}{c}\text { Chemical composition of } \\
\text { mild steel }\end{array}$ & \% \\
\hline $\mathbf{C}$ & $0.030 \%$ \\
\hline $\mathbf{M n}$ & $0.330 \%$ \\
\hline $\mathbf{S i}$ & $0.035 \%$ \\
\hline $\mathbf{P}$ & $0.014 \%$ \\
\hline $\mathbf{S}$ & $0.009 \%$ \\
\hline
\end{tabular}

Table.5 Mechanical properties of Steel fibers

\begin{tabular}{|c|c|}
\hline Diameter & $0.60 \mathrm{~mm}$ \\
\hline Length & $30 \mathrm{~mm}$ \\
\hline Tensile strength & $>1450 \mathrm{Mpa}$ \\
\hline $\begin{array}{c}\text { Tolerance for diameter } \\
\text { and length }\end{array}$ & $( \pm) 10 \%(\mathrm{AS} \mathrm{PER}$ \\
ASTM)
\end{tabular}

\section{EXPERIMENT PRESENTATION}

This investigation represents, warm restoring and relieved water are highly utilized. The size of $70.6 \mathrm{~mm} * 70.6 \mathrm{~mm} *$ $70.6 \mathrm{~mm}$ cube and Cylinder size of $150 \mathrm{~mm} * 300 \mathrm{~mm}$ are casted and presented with a temperature range of $200^{\circ} \mathrm{c}$ in macro-oven about 3 days with respect to time of $3 \mathrm{rd}$ day pursued with restored water upto 28 days. The expanded quality of compression is attained as $120 \mathrm{~N} / \mathrm{mm}^{2}$ by using nano-materials. 


\section{MIX PROPORTION}

Table.6 Mix Proportion of RPC with Variation in Glass powder in $\mathrm{kg} / \mathrm{m}^{3}$

\begin{tabular}{|c|c|c|c|c|}
\hline Materials & $\begin{array}{c}\text { M-0 } \\
100 \% \\
\text { C }\end{array}$ & $\begin{array}{c}\text { M-1 } \\
10 \% \\
\text { GP }\end{array}$ & $\begin{array}{c}\text { M-2 } \\
20 \% \mathrm{GP}\end{array}$ & $\begin{array}{l}\text { M-3 } \\
\mathbf{3 0 \%} \text { GP }\end{array}$ \\
\hline Cement & 750 & 675 & 600 & 525 \\
\hline $\begin{array}{l}\text { Silica } \\
\text { fume }\end{array}$ & 187.5 & 187.5 & 187.5 & 187.5 \\
\hline $\begin{array}{l}\text { Quartz } \\
\text { powder }\end{array}$ & 300 & 300 & 300 & 300 \\
\hline $\begin{array}{c}\text { River } \\
\text { sand }\end{array}$ & 934.2 & 934.2 & 934.2 & 934.2 \\
\hline $\begin{array}{c}\text { Glass } \\
\text { powder }\end{array}$ & - & 75 & 150 & 225 \\
\hline SP & 11.25 & 11.25 & 11.25 & 11.25 \\
\hline $\begin{array}{l}\text { Steel } \\
\text { fibers }\end{array}$ & 156.2 & 156.2 & 156.2 & 156.2 \\
\hline Water & 187.5 & 187.5 & 187.5 & 187.5 \\
\hline Net $w / b$ & 0.2 & 0.2 & 0.2 & 0.2 \\
\hline $\begin{array}{c}\text { Steel } \\
\text { fibers }\end{array}$ & $2 \%$ & $2 \%$ & $2 \%$ & $2 \%$ \\
\hline
\end{tabular}

C-Cement, GP-Glass powder

There is no need of mixing designing for RPC material which is acquired from literature review. From previous works, it is considered that cover/ water proportion is considered as 0.2. An ideal measurement of these steel-strands is proportion of $2 \%$ based on volume around $155 \mathrm{~kg} \cdot \mathrm{m}^{3}$. The powder of Quartz is taken as super-plasticizer and filter which is included blend supports the usefulness. The proportion of RPC material is mixed with the contrast of Glass-powder in respective tables.

\section{MIXING PROCEDURE}

The mixing method is adopted based on mixing of RPC which is relies on specific literature analysis [10]-[12]

- The machine of container blender (40kg-limit) is utilized to blend the RPC material.

- Pre-mix is deposited in blender skillet, and mixing is carried around three more minutes as well as blender is turning with a moderate speed. The consisted water (with $1 / 2$ of SP) should be included to pre-mix steadily with two-more minutes.

- After 1 minute, whatever remains of the SP should be added to pre-mix and mixing is carried with a medium speed range for a couple of minutes.

- As well as additionally the mixing is more significant at this intended speed upto the point when the moment that a uniform mix was expert and the mix was changed to a stream proficient with a consistency of self-compacting. The total usage time for mixing with diverse mixes kept running from 20 to 25 minutes.

- At final steel-ended strands are slowly added to mix, when the stream competent consistency was expert. After the strands were incorporated, mixing was continued for 2 more minute to provoke that the fiber occurs all around scattered.

\section{SPECIMEN CURING \& PREPARATION}

For every blend, three cubes are prepared and three barrels should be thrown. Size of 3D shape is $70.6 \mathrm{~mm} * 70.6 \mathrm{~mm} * 70.6 \mathrm{~mm}$, chamber measure is $150 \mathrm{~mm}$ diameter $\times 300 \mathrm{~mm}$ high. Cubes and are put in broiler at temperature of $200^{\circ} \mathrm{c}$. After warm restoring for 72 hours should be put in water upto testing date.

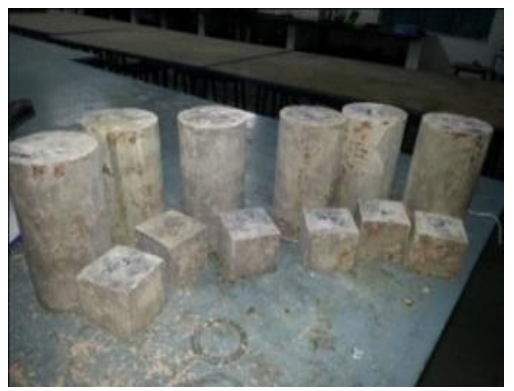

Fig.2. Specimens of cubes and cylinders

\section{TESTING}

Cylinders \& Cubes are tried for quality compression and elasticity with 28 more days individually. This can be tried in Compression Testing Machine (CTM) of 3000KN limit. According to 363R/929.99 The Modulus of Elasticity (GPa) is figured identified with compression Strength $\left(\mathrm{N} / \mathrm{mm}^{2}\right)$. Followed articulation is utilized,

Theoretical Modulus of Elasticity $=3.65 \sqrt{ } \mathrm{fc} \quad$ Where, $\mathrm{fc}$ is compressive strength

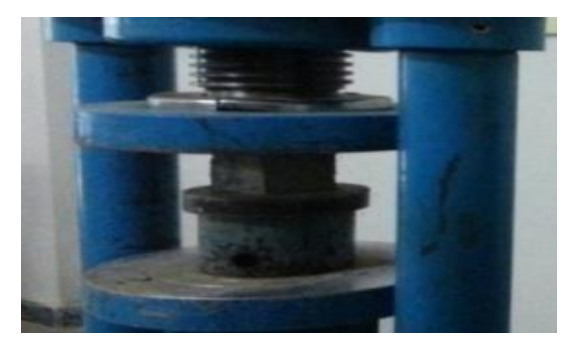

Fig.3. Compression test

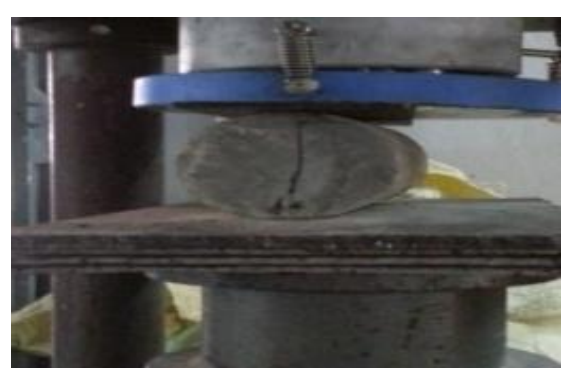

Fig.4. Split tensile test

\section{RESULTS \& DISCUSSION}

Arriving a perfect piece with locally available materials is basic to achieve compressive quality more than $120 \mathrm{~N} / \mathrm{mm}^{2}$. In this manner the effect of a couple of parameters on compressive quality were looked into which contain rates of powder of quartz, temperature range and diminishing organizations. 
An Experimental Model on the Mechanical Properties of Reactive Powder Concrete by using Cement Replacement of Glass Powder

In the midst of the mixing it was seen that the mixes appeared, apparently, to be especially fragile to any assortment of the sand, quartz powder are added as mixture upto the date doesn't have specified limitations for mixing. layout of RPC material, composing is insinuated the arrangement mixes.

\section{A. RPC MIXES WITH VARYING PERCENTAGE OF GLASS POWDER BY CALCULATING THE COMPRESSIVE STRENGTH}

Target mean Strength is accomplished when Glass powder is utilized. At the point when content of Glass powder is expanded, it is seen that quality is diminished. Greatest compressive quality for both multi day and 28 more days relieving is watched at $20 \%$ Glass powder for tests which is restored thermally for 72 more hours. The quality of compressive extents from $106 \mathrm{~N} / \mathrm{mm}^{2}$ to $132 \mathrm{~N} / \mathrm{mm}^{2}$ at $10 \%$ to $20 \%$ Glass powder under warm relieving at $200^{\circ} \mathrm{c}$ for 72 hours and 28 days for curing.

Table.7 Compressive strength in N/mm ${ }^{2}$

\begin{tabular}{|c|c|c|c|c|}
\hline \multirow{2}{*}{$\begin{array}{l}\text { Day of } \\
\text { curing }\end{array}$} & \multicolumn{4}{|c|}{ Compressive strength in $\mathrm{N} / \mathrm{mm}^{2}$} \\
\hline & Normal & $\begin{array}{l}10 \% \\
\text { GP }\end{array}$ & $\begin{array}{l}20 \% \\
\text { GP }\end{array}$ & $\begin{array}{l}\text { 30\% } \\
\text { GP }\end{array}$ \\
\hline 7 days & 98.2 & 100.4 & 115.3 & 105.7 \\
\hline 28 days & 103.6 & 106.2 & 132.4 & 109.8 \\
\hline
\end{tabular}

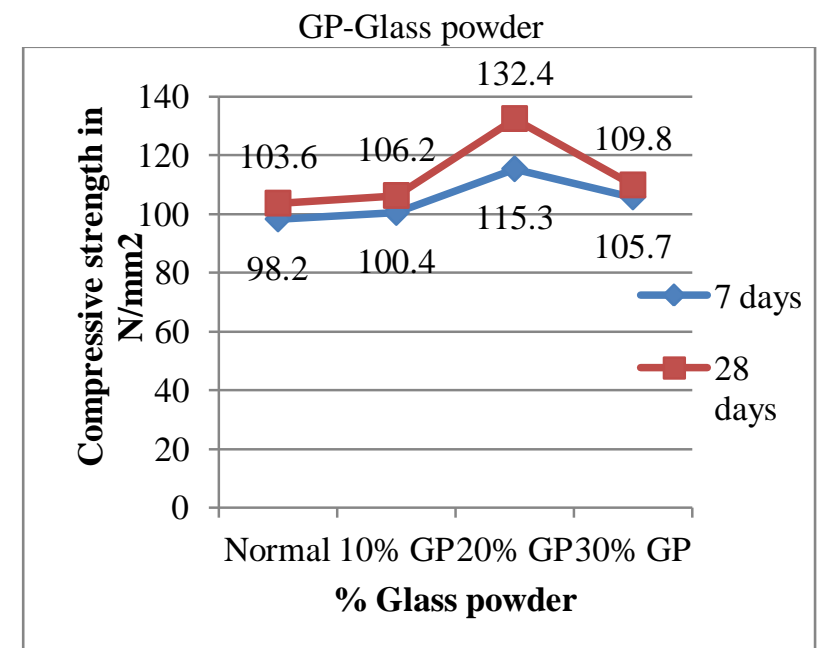

Graph.1 Variation of Compressive Strength versus \% of Glass powder

B. THE THEORETICAL MODULUS OF ELASTICITY

The modulus of hypothetic flexibility analysis with RPC by utilizing bond substitution of glass powder up to $30 \%$ and 72 hours warm restoring they are fixed in water upto testing date. Hypothetical modulus of flexibility results with fluctuating $\%$ of Glass powder is conceded in table. It is been seen that it ranges from $36 \mathrm{GPa}$ to $42 \mathrm{GPa}$ for $10 \%$ to $30 \%$ Glass powder warm relieving. Greatest hypothetical modulus of $42.01 \mathrm{GPa}$ is picked up for 72 hours warm restoring at $20 \%$ Glass powder.

Table.8 Modulus of Elasticity (GPa) results with varying $\%$ of Glass powder

\begin{tabular}{|l|l|l|l|l|}
\hline $\begin{array}{l}\text { Day of } \\
\text { curing }\end{array}$ & \multicolumn{4}{|l|}{ Modulus of elasticity in GPa } \\
\cline { 2 - 5 } & Normal & $\begin{array}{l}\mathbf{1 0 \%} \\
\text { GP }\end{array}$ & $\mathbf{2 0 \% \text { GP }}$ & $\mathbf{3 0 \%}$ GP \\
\hline
\end{tabular}

\begin{tabular}{|l|l|l|l|l|}
\hline 7 days & 36.17 & 36.57 & 39.19 & 37.52 \\
\hline 28 days & 37.15 & 37.61 & 42.01 & 38.24 \\
\hline
\end{tabular}

GP-Glass powder

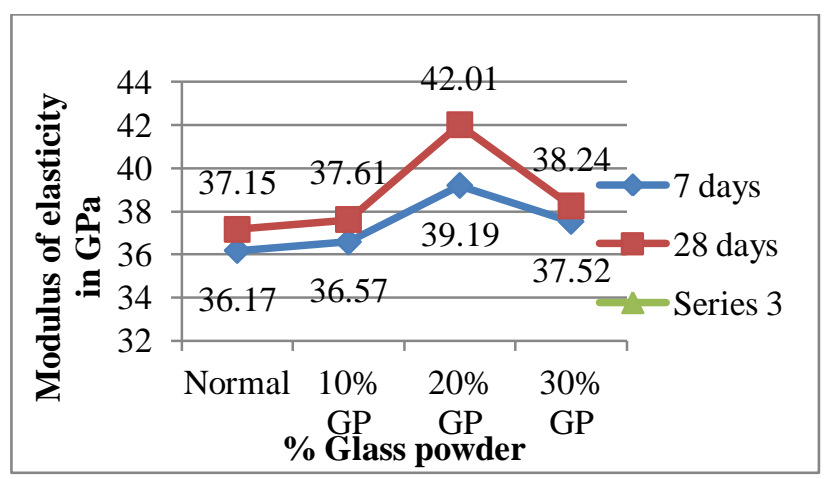

Graph.2 Variation of Theoretical modulus of elasticity by $\%$ of Glass powder

\section{SPLIT TENSILE STRENGTH OF RPC}

Split rigidity results with RPC by utilizing bond substitution of Glass powder up to $30 \%$ and 72 hours warm relieving they are set in water upto testing date. It is acquired that split rigidity ranges from $8 \mathrm{~N} / \mathrm{mm}^{2}$ to $16 \mathrm{~N} / \mathrm{mm}^{2}$.

Table.9 Split Tensile strength results with varying $\%$ of Glass powder in $\mathrm{N} / \mathrm{mm}^{2}$

\begin{tabular}{|l|l|l|l|l|}
\hline \multirow{2}{*}{$\begin{array}{l}\text { Day } \\
\text { curing }\end{array}$} & \multicolumn{4}{|l|}{ Split tensile strength in N/mm } \\
\cline { 2 - 5 } & Normal & $\begin{array}{l}\mathbf{1 0 \%} \\
\text { GP }\end{array}$ & $\begin{array}{l}\mathbf{2 0 \%} \\
\text { GP }\end{array}$ & 30\% GP \\
\hline 7 days & 8.2 & 9.4 & 11.8 & 10.8 \\
\hline 14 days & 12.4 & 13.3 & 16.2 & 14.5 \\
\hline
\end{tabular}

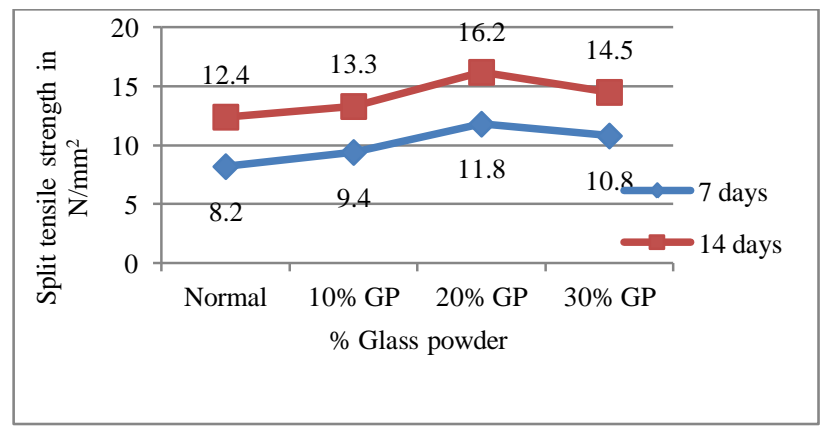

Graph.3 Variation of Split tensile strength by \% of Glass powder

\section{CONCLUSION}

Based on results, the following analysis represented as final conclusion

1. The RPC with strength of compressive higher than $130 \mathrm{~N} / \mathrm{mm}^{2}$ generated by using Cement replacement of Glass powder.

2. Compressive strength of RPC with $20 \%$ Glass powder is optimum at $200^{\circ} \mathrm{C}$ thermal curing for a period of 72 hours.

3. The high strength of compressive is $132.4 \mathrm{Mpa}$ achieved based on mix of $20 \%$ Glass powder and 72 more 
hours curing thermally at $200^{\circ} \mathrm{C}$.

4. The high split tensile strength of $16 \mathrm{Mpa}$ attained based on mix of $20 \%$ Glass powder and 72 more hours curing thermally at $200^{\circ} \mathrm{C}$.

5. The high Modulus of Elasticity of $42.01 \mathrm{MPa}$ acquired based on mix of $20 \%$ Glass powder and 72 more hours curing thermally at $200{ }^{\circ} \mathrm{C}$.

6. The high compressive strength with tensile strength, Modulus of Elasticity achieved at Glass powder of $20 \%$.

7. The obtained $\mathrm{P}^{\mathrm{H}}$ value of water which is utilized for curing cubes in this Research work is $\mathrm{P}^{\mathrm{H}} 7.23$.

\section{REFERENCES}

1. Pierre Richard, Marcel Cheyrezy, "Composition of Reactive Powder Concrete", Cement and Concrete Research Journal, 25(7), pp 1501-1511. 1995.

2. W. Kushartomo, Stabilization of Reactive Powder Concrete Strength Using Quartz Powder, Doctoral Dissertation, Tarumanagara University, Jakarta, 2014 (in Bahasa). H. Du, and K. H. Tan, Concrete with Recycled Glass as Fine Aggregates, ACI Materials Journal, Jan-Feb 2014, pp. 47-57.

3. K. M. Nag, C. M. Tam and V. W. Y. Tam "Studying the production process and mechanical Properties of reactive powder concrete", Magazine of Concrete Research, 2010, 62, No. 9, September, 647-654.

4. Harish K V, Dattatreya J K and Neelamegam M "Impact of fiber expansion, warm treatment, and preset weight on mechanical properties of ultra-high-quality mortars". 2011 Transportation Res. Rec. J. Transp.Res. Board 2240: 59-69.

5. Tam .C. M, Tam .V. W. Y., and. Ng K. M, "Optimal conditions for producing reactive Powder concrete" Magazine of Concrete Research, 2010, 62, No. 10, October, 701-716.

6. Maroliya M.K., "Mechanical Behaviour of modified of Reactive powder concrete", International journal of engineering research and applications, vol.2, sep-oct (2012),pp 2062-2067.

7. Prema Kumar W P, Ananthayya M B and Vijay K "Effect of Partial Replacement of Cement with Waste Glass Powder on the Properties of Concrete", IJSCER, Vol. 3, Issue. 2, pp.1-6, May 2014, ISSN: 2319-6009.

8. Dr. G. Vijayakumar, Ms H. Vishaliny and Dr. D. Govindarajulu, "Concentrates on Glass Powder as Partial Replacement of Cement in Concrete Production", International Journal of Engineering and Advanced Engineering (IJETAE), Vol. 3, Issue 2, Feb. 2013, pp. 153 157, ISSN: 2250-2459.

9. Prabhat R P, Bharatkumar B H and Iyer N R 2012 Mechanical properties of ultra high performance concrete. Proceedings of World Academy of Science, Engineering and Technology. No. 68. World Acad. Sci. Eng. Technol. 351(68): 1969.

10. Yang L S, Millard G S, Soutsos NM, Barnett J S and Le T T 2009 Influence of aggregate and curing regime on the mechanical properties of ultra-high performance fiber reinforced concrete (UHPFRC). Constr. Build. Mater. 23(6): 2291-2298.

11. Graybeal B A 2007 Compressive behavior of ultra-high-performance fiber-reinforced concrete. ACI Mater. J. 104(2): 146-152.

12. S. Snigdha Malya,V. K. Visweswara Rao A Study on the mechanical properties of reactive powder concrete using Granite powder and Nano silica IJIRSET AN ISO 3297:2007 certified organization vol. 5, Issue 11, NOV 2016 